\title{
Морфометрична оцінка структурної перебудови венозного русла товстої кишки при резекціях різних об'ємів паренхіми печінки
}

\begin{abstract}
Мета роботи: морфометрично вивчити особливості структурної перебудови венозного русла товстої кишки при резекціях різних об'ємів паренхіми печінки.

Матеріали і методи. Дослідження проведено на 60 щурах-самцях, які були розділені на 3 групи. 1-ша група нараховувала 20 інтактних тварин, 2-га - 20 щурів після резекції 31,5 \% паренхіми печінки, 3-тя - 20 тварин після видалення правої та лівої бокових часток печінки (58,1 \% паренхіми печінки). Евтаназію щурів здійснювали кровопусканням в умовах тіопенталнатрієвого наркозу через один місяць від початку експерименту. Із товстої кишки виготовляли гістологічні мікропрепарати, на яких вимірювали діаметри закапілярних венул, венул, зовнішній та внутрішній діаметри і товщину стінки венозних судин, висоту ендотеліоцитів, їх ядер, ядерно-цитоплазматичні відношення в ендотеліоцитах, відносні об’єми ушкоджених ендотеліоцитів. Кількісні показники обробляли статистично.

Результати досліджень та їх обговорення. Через місяць після резекції 58,1 \% об'єму печінки виявлено пострезекційну портальну гіпертензію. Встановлено, що при цьому діаметр закапілярних венул зріс на 37,0 \%, а діаметр венул - на 30,7 \% $(\mathrm{p}<0,001)$. В умовах пострезекційної портальної гіпертензії зовнішній діаметр вен товстої кишки з вираженою статистично достовірною різницею (р<0,001) зріс на 19,4 \%, внутрішній діаметр - на 36,6 \% ( $<0,001)$, а товщина стінки досліджуваних судин зменшилася на 11,9 \% (p<0,001). Висота ендотеліоцитів венозних судин товстої кишки при пострезекційній портальній гіпертензії статистично достовірно (p<0,001) зменшилася на 11,4 \% порівняно з контролем, діаметри їх ядер - на 9,3 \%, а ядерно-цитоплазматичні відношення в ендотеліоцитах зросли на 6,1 \% (p<0,001). Відносний об’єм ушкоджених ендотеліоцитів у досліджуваних умовах експерименту статистично достовірно збільшився у 22 рази (р<0,001) порівняно 3 аналогічним контрольним морфометричним параметром. Резекція великих об’ємів паренхіми печінки призводить до пострезекційної портальної гіпертензії та значного ремоделювання венозного русла товстої кишки, яке характеризується вираженим розширенням та повнокров'ям венозних судин, порушенням їх венозної дренажної функції, гіпоксією, дистрофічними, некробіотичними, інфільтративними та склеротичними процесами в досліджуваному органі.
\end{abstract}

Ключові слова: резекція печінки; товста кишка; венозне русло.

Постановка проблеми і аналіз останніх досліджень та публікацій. Резекцію печінки сьогодні нерідко виконують у хірургічних стаціонарах. Показаннями до даної операції є доброякісні та злоякісні пухлини, метастази, травми печінки, внутрішньопечінковий холангіолітіаз, альвеолярний ехінококоз, трансплантація печінки $[2,7,10]$. Відомо, що видалення великих об'ємів паренхіми печінки може призводити до виникнення пострезекційної портальної гіпертензії, для якої характерним $€$ розширення і повнокров'я ворітної печінкової вени, брижових вен, варикозне розширення вен стравоходу і шлунка, гемороїдальних вен, вен передньої черевної стінки, шлунковокишкові кровотечі, спленомегалія, асцит [2, 3, 6]. Товста кишка належить до органів, венозний дренаж від якої здійснюється через ворітну печінкову вену, де гемодинамічні розлади ускладнюються різними морфологічними змінами в судинах та структурах названого органа. Необхідно вказати, що особливості структурної перебудови венозного русла товстої кишки при резекції різних об'ємів паренхіми печінки вивчені недостатньо. Сьогодні морфометричні методи широко застосовують для вивчення ангіоархітектоніки інтраорганного судинного русла неушкоджених органів та при різних патологічних станах, де переважно локалізовані складні процеси взаємовідношень крові, тканин та клітин [1]. Інтраорганне венозне русло відіграє важливу роль у дренуванні венозної крові, порушення якого та структурні зміни венозних судин призводять до виражених порушень кровообігу, що суттєво впливає на повноцінність функціонування органів і систем. Варто зазначити, що венозні судини товстої кишки при при резекції різних об'ємів паренхіми печінки досліджені недостатньо.

Мета роботи: морфометрично вивчити особливості структурної перебудови венозного русла товстої кишки при резекціях різних об'ємів паренхіми печінки.

Матеріали і методи. Дослідження проведено на 60 щурах-самцях, які були розділені на 3 групи. 1-ша група нараховувала 20 інтактних тварин, 2-га - 20 щурів після резекції лівої бокової частки печінки (31,5 \% об’єму печінки), 3-тя - 20 тварин після видалення правої та лівої бокових часток пе- 
чінки (58,1 \% паренхіми печінки) [3]. Операційні втручання виконували в умовах тіопентал-натрієвого наркозу та 3 дотриманням правил асептики та антисептики. Евтаназія дослідних тварин здійснювалася кровопусканням в умовах тіопенталнатрієвого наркозу через один місяць від початку експерименту. Вирізані шматочки із клубової кишки фіксували в $10 \%$ нейтральному розчині формаліну і після відповідного проведення через етилові спирти зростаючої концентрації заливали у парафінові блоки за загальноприйнятою методикою. Мікротомні зрізи товщиною 5-7 мкм після депарафінізації забарвлювали гематоксилінеозином, за ван-Гізоном, Маллорі, Вейгертом, толуїдиновим синім [4]. На гістологічних препаратах морфометрично визначали діаметри закапілярних венул (ДЗВ), венул (ДВ), зовнішній (ДЗВС) та внутрішній (ДВВС) діаметри, товщину стінки (ТСВС) венозних судин, висоту ендотеліоцитів (BЕ), їх ядер (ДЯЕ), ядерно-цитоплазматичні відношення у ендотеліоцитах (ЯЦВЕ), відносні об'єми ушкоджених ендотеліоцитів (ВОПЕ) [1, 3]. Варто вказати, що виконані експериментальні дослідження та евтаназію дослідних тварин проводили із дотриманням "Загальних етичних принципів експериментів на тваринах”, ухвалених Першим національним конгресом із біоетики (Київ, 2001) та відповідно до “Європейської конвенції про захист хребетних тварин, що використовуються в дослідних та інших наукових цілях". Кількісні показники обробляли статистично. Обробка результатів виконана у відділі системних статистичних досліджень Тернопільського націо- нального медичного університету імені І. Я. Горбачевського МОЗ України в програмному пакеті STATISTIKA (“StatSoft Inc.”, США). Різницю між порівнювальними величинами визначали за критеріями Стьюдента та Манна-Уїтні $[1,5]$.

Результати досліджень та їх обговорення. Встановлено, що у дослідних тварин через місяць після резекції 31,5 \% паренхіми печінки гемодинамічних змін у системі ворітньої печінкової вени не виявлено. Більшість досліджуваних морфометричних параметрів венозного русла товстої кишки при цьому не змінювалася, крім відносного об’єму ушкоджених ендотеліоцитів. Збільшення останніх пояснюється зростанням кількості апоптично змінених клітин, що зустрічається у даних експериментальних умовах [3, 9].

У дослідних тварин через місяць після резекції 58,1 \% паренхіми печінки при розтині очеревинної порожнини спостерігалося розширення ворітної печінкової вени, повнокров'я і розширення брижових вен та видимого венозного русла тонкої та товстої кишок, асцит, спленомегалія. Слизова оболонка товстої кишки повнокровна, набрякла, з поодинокими осередками точкових кровови ливів. Описане вище свідчило про наявність пострезекційної портальної гіпертензії [3, 6].

Отримані при виконанні даної роботи кількісні морфологічні показники венозного русла товстої кишки експериментальних тварин представлено в таблиці. Усестороннім аналізом представлених морфометричних параметрів встановлено, що в умовах пострезекційної портальної гіпер-

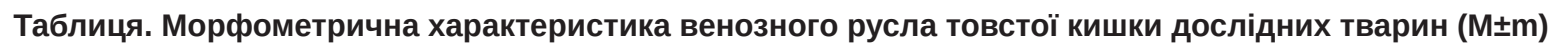

\begin{tabular}{||l|c|c|c||}
\hline \multirow{2}{*}{\multicolumn{1}{|c|}{ Показник }} & \multicolumn{3}{|c||}{ Група спостереження } \\
\cline { 2 - 4 } & 1 -ша & 2 -га & 3 -тя \\
\hline ДЗВ, мкм & $12,70 \pm 0,09$ & $12,72 \pm 0,09$ & $35,10 \pm 0,21^{* * *}$ \\
\hline ДВ, мкм & $26,85 \pm 0,18$ & $26,90 \pm 0,18$ & $48,60 \pm 0,52^{* * *}$ \\
\hline ДЗВС, мкм & $40,70 \pm 0,52$ & $40,74 \pm 0,57$ & $37,90 \pm 0,21^{* * *}$ \\
\hline ДВВС, мкм & $27,75 \pm 0,33$ & $27,84 \pm 0,36$ & $10,70 \pm 0,12^{* * *}$ \\
\hline ТСВС, мкм & $12,15 \pm 0,18$ & $12,90 \pm 0,18$ & $4,25 \pm 0,04^{* * *}$ \\
\hline ВЕ, мкм & $4,80 \pm 0,03$ & $4,82 \pm 0,05$ & $3,30 \pm 0,02^{* * *}$ \\
\hline ДЯЕ, мкм & $3,64 \pm 0,03$ & $3,66 \pm 0,04$ & $0,610 \pm 0,004^{* * *}$ \\
\hline ЯЦВЕ & $0,575 \pm 0,003$ & $0,576 \pm 0,004$ & $48,50 \pm 0,54^{* * *}$ \\
\hline ВОПЕ, \% & $2,20 \pm 0,03$ & $4,30 \pm 0,05^{* * *}$ & \\
\hline \hline
\end{tabular}

Примітка. $* * *-$ p $<0,001$ порівняно з 1-ю групою спостережень. 
тензії вони суттєво змінювалися. Відомо, що вени товстої кишки починаються із венозної ланки гемомікроциркуляторного русла (закапілярних венул та венул). Варто зазначити, що внутрішньоорганні вени неушкодженої товстої кишки за структурою суттєво відрізняються від артерій. У венах досліджуваного органа важко провести межу між внутрішнім, середнім та зовнішнім шарами судинної стінки. Стінки закапілярних венул представлені ендотелієм на базальній мембрані. У той же час, у вказаній структурі дрібних вен, крім ендотеліоцитів та базальної мембрани, локалізуються також гладкі м'язові клітини, еластичні та колагенові волокна, тобто вказані вени вже не беруть участі в обмінних процесах. Гладкі міоцити у стінках вен товстої кишки мають різні варіанти: в деяких венах вони повністю відсутні, а в інших розміщені в один шар. У місцях злиття вен м'язові структури розміщуються у 2-3 шари.

Встановлено, що через місяць після резекції 58,1 \% паренхіми печінки діаметр закапілярних венул статистично достовірно $(\mathrm{p}<0,001)$ зріс із $(12,70 \pm 0,09)$ мкм до $(17,54 \pm 0,12)$ мкм, тобто на $37,0 \%$. Діаметр венул гемомікроциркуляторного русла товстої кишки в умовах пострезекційної портальної гіпертензії статистично достовірно збільшився на 30,7 \% (p<0,001). При пострезекційній портальній гіпертензії ступінь розширення вен клубової кишки виявився меншим порівняно з венозними структурами (закапілярні венули та венули) гемомікроциркуляторного русла, що пояснюється наявністю гладких міоцитів у стінці венозних судин.

Так, в умовах пострезекційної портальної гіпертензії зовнішній діаметр вен товстої кишки 3 вираженою статистично достовірною різницею $(\mathrm{p}<0,001)$ зріс на $19,4 \%$, порівняно показником 1-ї групи спостережень, а внутрішній діаметр - на $36,6 \%$ (p<0,001). Товщина стінки досліджуваних судин із високим ступенем статистично достовірної різниці $(\mathrm{p}<0,001)$ зменшилася з $(12,15 \pm 0,18)$ мкм до $(10,70 \pm 0,12)$ мкм, тобто на $11,9 \%$.

Висота ендотеліоцитів венозних судин товстої кишки при пострезекційній портальній гіпертензії статистично достовірно $(\mathrm{p}<0,001)$ зменшилася на 11,4 \% порівняно $з$ контролем. Діаметри ядер ендотеліоцитів вен досліджуваного органа змінювалися аналогічно та їхнє зменшення відповідно складало 9,3 \%. Ядерно-цитоплазматичні відношення у ендотеліоцитах також виявилися суттєво зміненими у змодельованих експериментальних умовах, вказуючи на виражене порушення структурного клітинного гомеостазу $[1,3]$. При цьому вони зросли на $6,1 \%(\mathrm{p}<0,001)$. Відносний об'єм ушкоджених ендотеліоцитів у досліджуваних умовах експерименту статистично достовірно збіль- шився у 22 рази $(\mathrm{p}<0,001)$ порівняно з аналогічним контрольним морфометричним параметром.

При світлооптичному вивченні мікропрепаратів товстої кишки переважно у 3-й групі спостережень (резекція 58,1 \% паренхіми печінки) відмічалися виражені судинні розлади (повнокров'я переважно венозних судин, явища перивазального набряку, стази у венозній частині мікрогемоциркуляторного русла, осередки діапедезних крововиливів), дистрофічні, некробіотичні зміни епітеліоцитів, гладких міоцитів, ендотеліоцитів, стромальних структур, інфільтративні та склеротичні процеси. У деяких венах спостерігалися осередки з проліферацією ендотеліоцитів, що свідчило про наявність вираженої гіпоксії. В ядрах вказаних клітин виявлявся гіпохроматоз, пікноз та осередки лізису. Місцями контури стінок вен нечіткі, у них спостерігалося чергування набряклих та склеротичних вогнищ, а також гіпертрофованих та стоншених ділянок. Порушення венозного відтоку, депонування крові у венах супроводжується зростанням опору її руху, що призводить до гіпертрофії м'язової оболонки не тільки артеріол і артерій, але і деяких вен, що мало місце у наших спостереженнях. Ці явища відображають вено-артеріальну реакцію, спрямовану на збереження повноцінної мікроциркуляції у досліджуваному органі. Контури вен із нерівномірним просвітом, звивисті, покручені, їх звужені осередки з гіалінізованими стінками нерідко чергувалися з розширеними ділянками. Наведене свідчить, що змодельований експериментальний патологічний процес призводить до вираженої структурної перебудови всього венозного русла товстої кишки, тобто до структурнофункціональних змін всіх ланок їх венозної дренажної системи. Ушкодження значної кількості ендотеліоцитів, призводило до ендотеліальної дисфункції і посилювало гіпоксію [8].

Висновки. Резекція великих об'ємів паренхіми печінки призводить до пострезекційної портальної гіпертензії та ремоделювання венозного русла товстої кишки, яке характеризується вираженим розширенням та повнокров'ям венозних судин, порушенням їх венозної дренажної функції, гіпоксією, дистрофічними, некробіотичними, інфільтративними та склеротичними процесами у досліджуваному органі.

Перспективи подальших досліджень. Всебічне вивчення особливостей структурної перебудови венозного русла товстої кишки в умовах пострезекційної портальної гіпертензії дозволить суттєво розширити діагностику, корекцію та профілактику досліджуваної патології. 


\section{СПИСОК ЛІТЕРАТУРИ}

1. Автандилов Г. Г. Основы количественной патологической анатомии / Г. Г. Автандилов. - Москва : Медицина, 2002. - 240 с. 2. Волченко I. В. Особливості виконання обширних резекцій печінки 3 урахуванням профілактики післяопераційних ускладнень / І. В. Волченко, В. М. Лихман, Д. І. Скорий, А. М. Шевченко // Харківська хірургічна школа. - 2016. № 3 (78). - C. 35-39.

3. Гнатюк М. С. Морфометрична оцінка особливостей ремоделювання структур дванадцятипалої кишки при резекції різних об’ємів печінки / М. С. Гнатюк, Л. В. Татарчук, О. Б. Ясіновський // Науковий вісник Ужгородського університету. Серія “Медицина”. - 2016. - Вип. 1 (49). - С. 5-15.

4. Горальський Л. П. Основи гістологічної техніки. Морфофункціональні методи дослідження в нормі та при патології / Л. П. Горальський, В. П. Хомич, О. І. Кононський. - Житомир : Полісся, 2011. - 288 с

5. Гржибовский А. И. Сравнение количественных данных двух парных выборок с использованием программного обеспечения Statistica и SPSS: параметрические и непараметрические критерии / А. И. Гржибовский, О. В. Иванов, М. А. Горбатова // Наука и здравоохранение. - 2016. - Т. 3. - С. 5-25.

\section{REFERENCES}

1. Avtadnilov, G.G. (2002). Osnovy kolichestvennoy patologicheskoy anatomii [Basis of quantitative pathological anatomy]. Moscow: Meditsina [in Russian].

2. Volchenko, I.V., Lykhman, V.M., Skoryy, D.I., \& Shevchenko, A.M. (2016). Osoblyvosti vykonannia obshchyrnykh rezektsii pechinky z urakhuvanniam profilaktyky pisliaoperatsiinykh uskladnen [Peculiarities of performing extensive liver resections taking into account the prevention of postoperative complications]. Kharkivska khirurhichna shkola - Kharkiv Surgical School, 3 (78). 35-39 [in Ukrainian].

3. Hnatiuk, M.S., Tatarchuk, L.V., \& Yasinovskyy, O.B. (2016). Morfometrychna otsinka osoblyvostei remodeliuvannia struktur dvanadtsiatypaloi kyshky pry resektsii riznykh obiemiv pechinky [Morphometric evaluation of the features of remodeling of duodenal structures during resection of different volumes of the liver]. Naukovyi visnyk Uzhhorodskoho universytetu. Seriia "Medytsyna" - Scientific Herald of UzhHorod University. Series "Medicine", 1 (49), 3-5 [in Ukrainian].

4. Goralsky, L.P., Khomich V.T., Kononsky O.I. (2011).Osnovy histolohichnoyi tekhniky i morfofunktsionalni metody doslidzhen u normi i pry patolohiyi [Fundamentals of histological technique and morphofunctional research methods in normal and in pathology]. Zhytomyr: Polissia [in Ukrainian].

5. Grzhibovskiy A.I., Ivanov, O.V., \& Gorbatova, M.A. (2016). Sravneniye kolichestvennykh dannykh dvukh parnykh vyborok s vnedreniyem programmnogo obespecheniya Statistica i SPSS: parametricheskiye i neparametricheskiye kriterii [Comparison of
6. Дзигал О. Ф. Формування полісиндромної недостатності хворих на цироз печінки з портальною гіпертензією / О. Ф. Дзигал // Вісник наукових досліджень. - 2017. - № 2. - С. 88-92.

7. Дронов О. І. Хірургічне лікування вогнищевого ураження печінки: аналіз результатів та перспективи / О. І. Дронов, С. В. Земсков, Ю. П. Бакунець, П. П. Бакунець // Клінічна хірургія. - 2016. - № 1. - С. 28-31.

8. Охотнікова О. М. Ендотеліальна дисфункція як фактор розвитку тяжкого перебігу прогнозу системних васкулітів у дітей / О. М. Охотнікова, О. В. Поночевна, К. В. Меліна // Клінічна імунологія. Алергологія. Інфектологія. 2017. 2 (99). - C. 46-52.

9. Feng R. T. Molecular mechanism of low doze ionizing radiation in order to control bionegative effects to the organism and related human diseases / R. T. Feng, K. I. Weng // International Journal of Radiation Biology. - 2015. - Vol. 91. - P. 13-27.

10. Reddy S. S. From child-pugh to model for end-stage liver disease: Deciding who needs a liver transplant / S. S. Reddy, J. M. Civan // Med. Clin. Noth. Am. - 2016. - Vol. 100, No. 3. - P. 449-464. quantitative data of two paired samples using Statistica and SPSS software: parametric and nonparametric criteria]. Nauka i zdravookhraneniye - Science and Health, 3, 5-25 [in Russian].

6. Dzyhal, O.F. (2017). Formuvannia polisyndromnoi nedostatnosti khvorykh na tsyroz pechinky z portalnoiu hipertenziieiu [Formation of polysyndromic insufficiency of patients with liver cirrhosis with portal hypertension]. Visnyk naukovykh doslidzhen - Bulletin of Scientific Research, 2. 88-92 [in Ukrainian].

7. Dronov, O.I., Zemskov, S.V., Bakunets, Y.P., \& Bakunets, P.P. (2016). Khirurgicheskoye lecheniye ochagovogo porazheniya pecheni analiz rezultatov i perspektivy [Surgical treatment of focal liver disease: analysis of results and prospects]. Klinicheskaya khirurgiya - Clinical Surgery, 1, 28-31 [in Ukrainian].

8. Okhotnikova, O.M., Ponochevna, O.V., \& Mellina, K.V. (2017). Endotelialna dysfuntsiia yak faktor rozvytku tiazhkoho perebihu prohnozu systemnykh vaskulitiv u ditei [Endothelial dysfunction as a factor in the development of severe prognosis of systemic vasculitis in children]. Klinichna immunolohiia. Alerholohiia. Infektolohiia - Clinical Immunology. Allergology. Infectology, 2 (99), 46-52 [in Ukrainian].

9. Feng, R.T., \& Weng, K.I. (2015). Molecular mechanism of low doze ionizing radiation in order to control bionegative effects to the organism and related human diseases. International Journal of Radiation Biology, 91, 13-27.

10. Reddy, S.S., \& Civan, J.M. (2016). From child-pugh to model for end-stage liver disease: Deciding who needs a liver transplant. Med. Clin. Noth. Am., 100 (3), 449-464. 
M. S. HNATJUK, L. V. TATARCHUK, O. M. PROCAJLO, N. JA. MONASTYRSKA

I. Horbachevsky Ternopil National Medical University

\title{
MORPHOMETRIC EVALUATION OF STRUCTURAL RECONSTRUCTION OF THE VENOUS BED OF THE LARGE INTESTINE AT RESECTIONS OF DIFFERENT VOLUMES OF THE LIVER PARENCHYMA
}

\begin{abstract}
The aim of the work: morphometrically to study the features of structural reoconstruction of the venous bed of the large intestine at resections of different volumes of the liver parenchyma.

Materials and Methods. The studies were performed on 60 male rats, which were divided into 3 groups. Group 1 consisted of 20 intact animals, group $2-20$ rats after resection of $31.5 \%$ of the liver parenchyma, group $3-20$ animals after removal of the right and left lateral lobes of the liver ( $58.1 \%$ of the liver parenchyma). Euthanasia of animals was performed by bloodletting under conditions of thiopental anesthesia 1 month after the start of the experiment. Histological micronutrients were made from the large intestine. The diameters of capillary venules, venules, outer and inner diameters and wall thickness of venous vessels, height of endotheliocytes, their nuclei, nuclear-cytoplasmic relations in endotheliocytes, relative volumes of damaged endotheliocytes were measured. Quantitative indicators were processed statistically.

Results and Discussion. One month after resection of $58.1 \%$ of the liver volume, postresection portal hypertension was detected. It was found that the diameter of the capillary venules increased by $37.0 \%$ and the venules - by $30.7 \%(p<0.001)$. At postresection portal hypertension, the outer diameter of the veins of the large intestine with a pronounced statistically significant difference $(\mathrm{p}<0.001)$ increased by $19.4 \%$, the inner diameter - by $36.6 \%(\mathrm{p}<0.001)$, and the wall thickness decreased by $11.9 \%(\mathrm{p}<0.001)$. The relative volume of damaged endotheliocytes in the studied experimental conditions increased statistically significantly 22 times (p <0.001) compared with a similar control morphometric parameter. Resection of large volumes of liver parenchyma leads to postresection portal hypertension and significant remodeling of the venous bed of the colon, which is characterized by pronounced dilation and plethora of venous vessels, violation of their venous drainage function, hypoxia, dystrophic, necrobiotic, infiltrative and sclerotic processes in the studied organ.
\end{abstract}

Key words: resection liver; large intestine; venous bed.

М. С. ГНАТЮК, Л. В. ТАТАРЧУК, О. М. ПРОЦАЙЛО, Н. Я. МОНАСТЫРСКАЯ

Тернопольский национальный медицинский университет имени И. Я. Горбачевского МОЗ Украины

\section{МОРФОМЕТРИЧЕСКАЯ ОЦЕНКА СТРУКТУРНОЙ ПЕРЕСТРОЙКИ ВЕНОЗНОГО РУС.А ТОЛСТОЙ КИШКИ ПРИ РЕЗЕКЦИЯХ РАЗЛИЧНІЬХ ОБЪЕМОВ ПАРЕНХИМЫ ПЕЧЕНИ}

\begin{abstract}
Цель работы: морфометрически изучить особенности структурной перестройки венозного русла толстой кишки при резекциях различных объмов паренхимы печени.

Материалы и методы. Исследования проведены на 60 крысах-самцах, которые были разделены на 3 группы. 1-я группа насчитывала 20 интактных животных, 2-я - 20 крыс после резекции 31,5 \% паренхимы печени, 30-я - 20 животных после удаления 58,1 \% паренхимы печени. Эвтаназия крыс осуществлялась кровопусканием в условиях тиопентал-натриевого наркоза через один месяц после начала эксперимента. С толстой кишки изготавливали гистологические микропрепараты, на которых измеряли диаметры посткапиллярных венул, венул, внешний и внутренний диаметры, толщину стенки венозных сосудов, высоту эндотелиоцитов, их ядер, ядерно-цитоплазматические отношения в эндотелиоцитах, относительные объемы поврежденных эндотелиоцитов. Количественные показатели обрабатывали статистически.

Результаты исследований и их обсуждение. Через месяц после резекции 58,1\% объема печени обнаружена пострезекционная портальная гипертензия. Выявлено, что при этом диаметр посткапиллярных венул вырос на 37,0 \%, а венул - на 30,7 \% $(\mathrm{p}<0,001)$. В условиях пострезекционной портальной гипертензии внешний диаметр вен толстой кишки с выраженным статистически достоверным различием (р<0,001) увеличился на 19,4 \%, внутренний диаметр - на 36,6 \% ( $<0,001)$, а толщина стенки исследуемых сосудов уменьшилась на 11,9 \% (p <0,001). Высота эндотелиоцитов венозных сосудов толстой кишки при пострезекционной портальной гипертензии статистически достоверно ( $<0,001)$ уменьшилась на $11,4 \%$ по сравнению с контролем, диаметры их ядер - на 9,3 \%, а ядерно-цитоплазматические отношения в эндотелиоцитах выросли на 6,1 \% (p<0,001). Относительный объем поврежденных эндотелиоцитов в исследуемых условиях эксперимента статистически достоверно увеличился в 22 раза $(\mathrm{p}<0,001)$ по сравнению с аналогичным контрольным морфометрическим параметром. Резекция больших объемов паренхимы печени приводит к пострезекционной портальной гипертензии и значительному ремоделированию венозного русла толстой кишки, характеризующееся выраженным расширением и полнокровием венозных сосудов, нарушением их венозной дренажной функции, дистрофическими, некробиотическими, инфильтративными и склеротическими процессами в исследуемом органе.
\end{abstract}

Ключевые слова: резекция печени; толстая кишка; венозное русло. 